\title{
DIFFERENCES AND SIMILARITIES AMONG RURAL TOURISM IN SLOVENIA AND SERBIA - PERCEPTIONS OF THE LOCAL TOURISM WORKERS ${ }^{1}$
}

\author{
Aleksandra Vujko², Marko D. Petrović3 ${ }^{3}$,Miloš Dragosavac ${ }^{4}$, Tamara Gajic ${ }^{5}$
}

\begin{abstract}
Summary
This paper deals with the development of rural areas in Slovenia and Serbia and gives some differences/similarities among these two countries based on perception of 492 tourism workers. The article making a series of proposals to guide the future research agenda. The main aim of the paper is to point out the benefits of rural tourism development and it's similarities and differences in Slovenia and Serbia. The data for this study were collected using Dwyer and Kim's (2003) Integrated Model of Destination Competitiveness to observe Slovenia's and Serbia's rural tourism differences/similarities. Determinants were assessed using a survey evaluating 24 indicators (demand and supporting factors), based upon a Likert Scale.
\end{abstract}

Key words: rural tourism, Integrated Model of Destination Competitiveness, Slovenia, Serbia JEL classification: Q15, R11

\section{Introduction}

Recent studies have found that rural tourism can enhance the identity of the entire country because it is strongly related to ways of life, local production, cultural celebration and heritage (Everett, Aitchison, 2008; Bole et al., 2013; Ursache, 2015). During the visit to a destination, tourists have the opportunity to experience the amenities and attractions of the rural area and it is likely that a positive experience will influence the likelihood

1 The research was supported by Ministry of Education, Science and Technological Development, Republic of Serbia (Grant III 47007).

2 Aleksandra Vujko Ph.D., Lecturer, Novi Sad Business School, Vladimira Parića Valtera street no. 4, Novi Sad, Serbia, Phone: +381 6491426 45, E-mail: aleksandravujko@yahoo.com

3 Marko D. Petrović Ph.D., Research Associate, Geographical Institute "Jovan Cvijić", Serbian Academy of Sciences and Arts (SASA), Djure Jakšića street no. 9, 11000 Belgrade, Serbia, Email: m.petrovic@gi.sanu.ac.rs

4 Miloš Dragosavac, Assistent, Novi Sad Business School, Vladimira Parića Valtera street no. 4, Novi Sad, Serbia, E-mail: dragosavac.vps@gmail.com

5 Tamara Gajić Ph.D., Professor of professional studies, Novi Sad Business School, Vladimira Perića Valtera street no. 4, Novi Sad, Serbia, Phone: +381 63565 544, E-mail: gajic tamara@yahoo.com

EP 2016 (63) 4 (1459-1469) 
of a return visit (Kompulla, 2014). Organised rural tourism in Slovenia started at the beginning of the 1970s (Košćak, 1998; Erjavec et al., 1998; Knežević, Cvelbar, 2011). The country has undergone a long process from the foundation of advisory services, training of the rural population, co-financing model creation, establishing minimal technical conditions and categorisation; engaging ethnologists, architects, agronomist, food technologists; to establishing associations, creating rural tourism product, catalogue design and other marketing promotional activities (Lock et al., 2004; Dwyer et al., 2012). As Estol and Font (2016) stated, at present, this tourism branch is compliance with domestic and European laws. The number of households that offer services in rural tourism is six hundred out of which 38 are specialised accommodation facilities households. Total capacity is 2,000 beds and annual occupancy rate is $70 \%$ (Armenski et al., 2012).

Rural tourism is given priority in Serbian National Sustainable Development Strategy (2007), since it is observed as a high potential sector with vertical institutional structure supporting its development. About 1,000 rural households have been registered offering tourism and hospitality services in Serbia. Tourism is a primary activity for about 300 household members. The total offer comprises about 8,000 beds. A single household establishment has between 750 and 1,500 overnight stays. About 60 households have over 1,000 overnights and 240 households have between 700 and 1,000 overnights and 150 households have between 350 and 700 overnights. Average length of stay in a household is 2.8 days (Petrović, 2014; Petrović et al., 2016b).

The main aim of this study is to point out the main differences and similarities in rural tourism among two countries based on perception of tourism workers, with objective to point out the potential benefits of rural tourism development. The authors compared these two destinations because these countries were former Yugoslavia until 1991, when Slovenia became an independent state. As former states of Yugoslavia, these two countries have many geographical, historical, and cultural similarities.

\section{Literature review}

Rural tourism is significant factor of multifunctional and sustainable rural development, which has been confirmed by numerous theoretical and empirical researches (Campbell, 1999; Getz, Carlsen, 2000; Gaddefors, 2005; Getz, Carlsen, 2005; Brankov et al., 2015; Srdanović, Pavić, 2015). The decrease of traditional subventions for agriculture makes rural tourism more and more important as a key form of diversification, which supports economically sustainable rural communities.

There are two approaches to rural tourist activities. The first, traditional way, comprises a passive visitors' stay in a farm-based accommodation in a rural environment, with passive watching of host activities without any significant involvement. Such approach is defined as Life-seeing and it is less present in the international tourist courses. On the other hand, the contemporary concept, known as Life-participating, represents a new, modern way of visitors' spending time on the farms, with active involvement in most of the agricultural and 
other available work at the farms (Sidali et al., 2011; Petrović et al., 2015; 2016a). According to Lane (1994), rural tourism should be based in those areas which are rural in all aspects, and it is a key factor of rural areas revitalisation process. Dimitrovski et al., (2012) stated that the rural areas have a unique opportunity to attract tourists by the means of establishing a connection between rural areas and their cultural, historic, ethnic and geographical roots.

This study is based on modified Dwyer and Kim's (2003) Integrated Model of Destination Competitiveness, previously employed in similar recent case-studies (e.g. Dwyer et al., 2004; Gomezelj, Mihalič, 2008; Dragićević et al., 2012; Chee-Hua Chin et al., 2014). The Integrated Model of Destination Competitiveness was deemed the most appropriate model because it provides tourism stakeholders and researchers insight pertaining what is needed to identify and what changes are essential to reduce the negative differences. The original Integrated Model of Destination Competitiveness was conducted in the form of survey questionnaire that was divided into six main determinants of destination competitiveness involving: Inherited Resources; Created Resources; Supporting Factors; Destination Management; Demand Conditions and Situational Conditions.

\section{Research Methodology}

Modification of the original Model has been developed for the purposes of this paper and only 2 factors have been presented based on 24 indicators (Supporting Factors and Demand Conditions). We concluded that 24 indicators identified by Dwyer and Kim (2003) are appropriate for measuring some differences and similarities among two countries based on perception of tourism workers. The results presented in the following section display mean values and standard deviations for each indicator. Indicators with mean values greater than 3.00 are regarded as competitive (Mulec, Wise, 2013).

The questionnaires were gathered between 2013 and 2016. Some of the questionnaires were self-directed, others were sent by mail. Respondents were selected among Serbian (mainly from Vojvodina Province in Northern Serbia) and Slovenian rural tourism workers including members of National Association "Rural Tourism of Serbia", members of Business Association of hotel and restaurant industry of Serbia, employees from six farm-based accommodations (Dida Hornjakov salaš, located near Sombor, Salaš 137 in Čenej, near Novi Sad, Majkin salaš in Palić, Katai salaš from Mali Iđoš, Cvejin salaš in Begeč, and Perkov salaš near Neradin in Fruška Gora National Park), managers and employees from travel agencies Panacomp Rural Hospitality Net and Magelan from Novi Sad, members of Association "UGONS 1946" and members of Association of Tourists guides of Novi Sad, total 276 tourist workers from Serbia, and members of Slovenian Tourist guides, members of Association of Tourists Agencies of Slovenia, members of National Tourists Association - NTA, members of International Tourism Institute and Association of Tourists Farms of Slovenia, total 216 of tourist workers.

All of 492 respondents were asked to rate Slovenia's and Vojvodina's supporting and demand factors on a five-point Likert Scale for all 26 indicators, ranging from 1) Not competitive; 2) Partially competitive; 3) No opinion; 4) Competitive; 5) Strongly competitive. 
The first step in the analysis was to look at some basic descriptive statistics (arithmetic means and standard deviations) of these responses. These frequency distributions clearly indicate one important aspect of the answers given: Slovenian responders gave consistently higher ratings than the respondents from Serbia. The SPSS standard package for personal computers was used for data processing.

Table 1. Type of respondents by country

\begin{tabular}{|l|c|c|}
\hline \multicolumn{1}{|c|}{ Type of respondent from Serbia } & Frequency & Percent \\
\hline Members of National Association "Rural Tourism of Serbia” & 64 & 3.2 \\
\hline $\begin{array}{l}\text { Members of Business Association of hotel and restaurant industry - } \\
\text { Serbia }\end{array}$ & 47 & 17.0 \\
\hline $\begin{array}{l}\text { Managers and employees from 6 farms (Dida Hornjakov salaš, located } \\
\text { near Sombor, Salaš 137 in Čenej, near Novi Sad, Majkin salaš in Palić, } \\
\text { Katai salaš from Mali Iđoš, Cvejin salaš in Begeč, and Perkov salaš near } \\
\text { Neradin in Fruška Gora National Park }\end{array}$ & 37 & 13.4 \\
\hline $\begin{array}{l}\text { Managers and employees from travel agencies Panacomp Rural } \\
\text { Hospitality Net and Magelan from Novi Sad }\end{array}$ & 9 & 3.3 \\
\hline Members of Association "UGONS 1946" & 42 & 15.2 \\
\hline Members of Association of Tourists guides of Novi Sad & 77 & 27.9 \\
\hline \multicolumn{1}{|c|}{ Type of respondent from Slovenia } & 276 & 100 \\
\hline \multicolumn{1}{|c|}{ Total } & Frequency & Percent \\
\hline Members of Slovenian Tourist guides & 48 & 22.2 \\
\hline Members of Association of Tourists Agencies of Slovenia & 55 & 25.5 \\
\hline Members of National Tourists Association - NTA & 62 & 23.6 \\
\hline $\begin{array}{l}\text { Members of International Tourism Institute and Association of Tourists } \\
\text { Farms of Slovenia }\end{array}$ & 216 & 100 \\
\hline
\end{tabular}

Source: Own calculations

\section{Results and discussion}

Comparative analysis (Table 2) may position rural tourism of Serbia regarding Slovenia with which it shares numerous geographical, demographical, and other similar characteristics (Rey, Groza, 2009; Grum, Kobal-Grum, 2014). Comparison of economic indicators in Slovenia and Serbia has been done.

Table 2. Comparative analysis of the rural tourism development in Slovenia and Serbia in 2013

\begin{tabular}{|l|c|c|}
\hline & Serbia & Slovenia \\
\hline Rural area (\% of the total territory) & $85 \%$ & $90 \%$ \\
\hline Rural population (\% of the total population) & $48 \%$ & $57 \%$ \\
\hline Population density in rural areas (inhabitants $/ \mathrm{km}^{2}$ ) & 84 & 102 \\
\hline Mean unemployment rate in rural areas & $21 \%$ & $9 \%$ \\
\hline Number of households offering tourism services & 300 & 600 \\
\hline Mean annual number of overnight stays & 150.000 & 300.000 \\
\hline
\end{tabular}




\begin{tabular}{|l|c|c|}
\hline Mean length of stay (days) & 2.8 & 3.7 \\
\hline Total accommodation capacities (number of beds) & 8.000 & 6.000 \\
\hline Mean utilization of capacities & $40 \%$ & $70 \%$ \\
\hline Mean profit per a household (annual in Euro) & 2.500 & 10.000 \\
\hline
\end{tabular}

Source: National statistical Office of Slovenia and Serbia

Supporting factors refer to general infrastructures, quality of service, accessibility, hospitality and market ties (Dwyer, Kim, 2003). Some of supporting factors displayed in Table 3, show potential competitiveness while the rest display averages below 3.00.

Table 3. Mean and standard deviations (SD) for supporting factors for Serbia and Slovenia

\begin{tabular}{|c|c|c|}
\hline Competitiveness indicator for Serbia (Vojvodina) & Mean & SD \\
\hline Friendliness of residents towards tourists & 3.33 & 0.793 \\
\hline Distance/flying time to destination & 3.89 & 0.608 \\
\hline Ease of communication between residents and tourists & 4.34 & 0.633 \\
\hline Financial institution and currency exchange facilities & 2.18 & 0.729 \\
\hline Telecommunication system & 3.69 & 0.750 \\
\hline Resident support for the tourism industry & 2.17 & 0.616 \\
\hline Ease/cost of obtaining entry Visa & 2.62 & 0.727 \\
\hline Ethnic ties with major tourist origin markets & 2.88 & 0.669 \\
\hline Ease of combining travel to destination & 4.16 & 0.569 \\
\hline Awareness of tourism employees about quality of services & 3.50 & 0.721 \\
\hline Sporting links with major tourist origin markets & 2.99 & 0.716 \\
\hline Health/medical facilities to serve tourists & 4.10 & 0.513 \\
\hline Business ties/trade links with major tourist origin markets & 2.56 & 0.633 \\
\hline Tourism firms have programs to ensure/monitor visitor satisfaction & 3.31 & 0.833 \\
\hline Adequacy of infrastructure & 2.23 & 0.582 \\
\hline Local transport systems & 1.89 & 0.686 \\
\hline Existence of resident hospitality development programs & 3.40 & 0.823 \\
\hline Development of training programs to enhance quality of service & 2.88 & 0.552 \\
\hline Waste disposal & 2.06 & 0.716 \\
\hline Tourism/hospitality firms have well defined performance standards & 1.97 & 0.593 \\
\hline Competitiveness indicator for Slovenia & Mean & SD \\
\hline Friendliness of residents towards tourists & 4.43 & 0.849 \\
\hline Distance/flying time to destination & 4.38 & 0.833 \\
\hline Ease of communication between residents and tourists & 4.51 & 0.772 \\
\hline Financial institution and currency exchange facilities & 3.84 & 0.953 \\
\hline Telecommunication system & 4.95 & 0.371 \\
\hline Resident support for the tourism industry & 4.69 & 0.589 \\
\hline Ease/cost of obtaining entry Visa & 4.56 & 0.673 \\
\hline Ethnic ties with major tourist origin markets & 4.30 & 0.700 \\
\hline Ease of combining travel to destination & 4.22 & 0.620 \\
\hline Awareness of tourism employees about quality of services & 4.60 & 0.740 \\
\hline Sporting links with major tourist origin markets & 4.47 & 0.661 \\
\hline
\end{tabular}




\begin{tabular}{|l|c|c|}
\hline Health/medical facilities to serve tourists & 4.14 & 0.697 \\
\hline Business ties/trade links with major tourist origin markets & 3.56 & 0.938 \\
\hline Tourism firms have programs to ensure/monitor visitor satisfaction & 4.62 & 0.614 \\
\hline Adequacy of infrastructure & 4.59 & 0.580 \\
\hline Local transport systems & 4.45 & 0.720 \\
\hline Existence of resident hospitality development programs & 4.55 & 0.667 \\
\hline Development of training programs to enhance quality of service & 4.63 & 0.698 \\
\hline Waste disposal & 3.69 & 0.789 \\
\hline Tourism/hospitality firms have well defined performance standards & 4.17 & 0.737 \\
\hline
\end{tabular}

Source: Own calculations

Demand factors involve destination image/perception and awareness of tourism products (Table 4). Survey participants determined Vojvodina's and Slovenia's overall competitiveness perception as being competitive, although only one variable averaged below 3.00 (destination image and perception in the world).

Table 4. Mean and standard deviations (SD) for demand factors for Serbia and Slovenia

\begin{tabular}{|l|c|c|}
\hline \multicolumn{1}{|c|}{ Competitiveness indicator for Serbia (Vojvodina) } & Mean & SD \\
\hline Overall perception of Vojvodina as a tourism destination & 4.13 & 0.490 \\
\hline Destination awareness & 3.89 & 0.625 \\
\hline Awareness of tourism products of Vojvodina abroad & 4.13 & 0.475 \\
\hline Destination image and perception in the world & 2.54 & 0.668 \\
\hline \multicolumn{1}{|c|}{ Competitiveness indicator for Slovenia } & Mean & SD \\
\hline Overall perception of Slovenia as a tourism destination & 4.69 & 0.555 \\
\hline Destination awareness & 4.69 & 0.553 \\
\hline Awareness of tourism products of Slovenia abroad & 4.85 & 0.472 \\
\hline Destination image and perception in the world & 4.87 & 0.458 \\
\hline
\end{tabular}

Source: Own calculations

Rural tourism stakeholders across the various state sectors of Slovenian and Serbian rural tourism evaluated how important these actions were to the industry's future development and their performance in respect of these actions. In recent decades, tourism development in Serbia has not attached great importance, which resulted in low competitiveness in the international market (Petrović-Ranđelović, Miletić 2012). Rural development in Serbia has been defined as economic, social and ecological priority by the Government of the Republic of Serbia. Diversification of rural economy towards socially, economically and ecologically sustainable form aims at improving the quality of living, lowering the poverty, as well as against social and ecological degradation (Vujko, Gajić, 2014).

These aims are directed primarily towards elimination of poverty, sustainable environment protection and global partnership development. It can be said that modest knowledge and lack of supplementary skills in rural population have been confirmed by the data according to which $97 \%$ of the rural population in Serbia failed to attend skills training programs and 
$54 \%$ of the rural population lacks special knowledge and skills (Petrović, 2014). Such results are unfavorable for the total capacity and competitiveness of the labor force in rural areas (Table 1). Low quality of the labor force may be observed as one of the burdening factors in economic development of rural areas, since it causes low entrepreneur potential of rural population, as well as low economic interest of foreign investors (Hall 1998).

Statistical data in rural tourism are based on estimations both for capacities and turnover (Đukičin et al., 2014). Since rural areas in Serbia account for $85 \%$ of the territory significant number of overnight stays realized in mountain and spa areas (Vujko, Gajć, 2014), as well as in other tourism or non-tourism places may be recorded as the overnight stays in this tourism segment. Despite the relatively low averages of variables among supporting factors observed in Table 3, the most competitive indicator is hospitality. Today, it is estimated that about 300 rural households with 8,000 beds offer services and realize over 150,000 overnights annually (Petrović, 2014). This leads to a conclusion that tourism is a service oriented activity dependent upon interaction, contact and communication with visitors.

Adversely to Serbia, Slovenia raised tourism services to a higher level (Table 3). According to the type and content of tourism services, Slovenia legally defined three types of tourism farms (rural households): open door farms, tourist farms and wineries. Quality classification system is determined by one, two, three and four apples. Categorisation is performed when all the conditions for the start of a tourism farm are met. Although they can boast with guests staying for two months, the present trend indicates shorter stays. Weekends are booked throughout the year which indicates that there is no high and low season. Since 1970s (Košćak, 1998) Slovenian government and rural household owners have been making joint efforts to achieve this high level and become compared with France and Italy, the leaders in rural tourism industry.

\section{Conclusion}

This research may lead to the conclusion that both countries have equal percentages of rural territories, however with different levels of development. Rural population percentage is larger in Slovenia with 57\%. Moreover, Slovenian population density is higher (Šprah et al., 2014). According to mean unemployment rate in rural areas, critical situation is observed in Serbia with about $21 \%$ of the unemployed. Slovenia also leads in the number of households that offer tourism services with 600 households and over 300,000 annual overnight stays regarding Serbia with only 300 households and 150,000 annual overnight stays. Furthermore, the length of stay for tourist visiting rural areas is longer for Slovenia with 3.7 days, whereas for Serbia the number is only 2.8 days. The higher utilization of accommodation capacities is recorded for Slovenia, $70 \%$, whereas the utilizations significantly lower, only $40 \%$. Mean profit values per a household are higher for Slovenia (10,000 Euro) and lower in Serbia (2,500 Euro) (Šprah et al., 2014; Petrović, 2014). The results provide strong empirical support for the inclusion of rural tourism destination attributes in studies of tourism competitiveness.

The potential benefits of rural tourism development are numerous and requires a serious approach. The present level of competitiveness in Serbia in rural tourism industry is 
far from good, although there are natural, cultural and social preconditions for its development (Todorović, Bjeljac, 2009). Contrary to that, developed rural tourism in Slovenia contributes not only to higher profit gain by households, but also to variety of tourism offer, preserving tradition, ethnological uniqueness (Šmid-Hribar, LedinekLozej, 2013), limiting depopulation of the villages and improving the quality of living in a village (Bole et al., 2013; Nastran, 2015). It can be concluded that Serbia must follow Slovenia and follow her example of good practice.

\section{References}

1. Armenski, T., Gomezelj, D., Djurdjev, B., Ćurčić, N., Dragin, A. (2012): Tourism destination competitiveness - Between two flags. Economic Research, vol. 25, pp. 485-502.

2. Bole, D., Pipan, P., Komac, B. (2013): Cultural values and sustainable rural development: A brief introduction. Acta geographica Slovenica, vol. 52, no. 2, pp. $367-$ 370.

3. Brankov, J., Jovičić, D., Milijašević, D. (2015): Sustainable Tourism in National Park “Đerdap”, Serbia - Attitudes of Local Population. Journal of the Geographical Institute "Jovan Cvijić" SASA, vol. 65, no. 2, pp. 183-199.

4. Campbell L. M. (1999): Ecotourism in rural developing communities. Annals of Tourism Research, vol. 26, no. 3, pp. 534-553.

5. Dimitrovski, D.D., Todorović, A.T., Valjarević, A.D. (2012): Rural tourism and regional development: Case study of development of rural tourism in the region of Gruza, Serbia. Procedia Environmental Sciences, vol. 14, pp. 288-297.

6. Todorović, M., Bjeljac, Ž. (2009): Rural tourism in serbia as a concept of development in undeveloped regions. Acta geographica Slovenica, vol. 49, no. 2, pp. 453-473.

7. Chin, C.H., Lo, M.C., Songan, P., Nair, V. (2014): Rural Tourism Destination Competitiveness: AnStudy on Annah Rais Longhouse Homestay, Sarawak. Procedia Social and Behavioral Sciences, vol. 144, no. 20, pp. 35-44.

8. Dwyer, L., Knežević Cvelbar, Lj., Edwards, D., Mihalic, T. (2012): Fashioning A Destination Tourism Future: The Case Of Slovenia. Tourism Management, vol. 33, no. 2, pp. 305-316.

9. Dragićević, V., Jovičić, D., Blešić, I., Stankov, U., Bošković, D. (2012): Business tourism destination competitiveness: A case of Vojvodina Province (Serbia). Economic Research, vol. 25, pp. 311-332.

10. Dwyer, L., Mellor, R., Livaic, Z., Edwards, D., Kim, C.W. (2004): Attributes of destination competitiveness: A factor analysis. Tourism Analysis, vol. 9, pp. 91-102.

11. Dwyer, L., Kim, C. (2003): Destination competitiveness: Determinants and indicators. Current Issues in Tourism, vol. 6, pp. 369-413.

12. Đukičin, S., Đorđević, J., Milanković, J. (2014): Spatial and social changes caused by the continuous exploitation of lignite in the Kolubara lignite basin, Serbia. Acta geographica Slovenica, vol. 54, no. 1, pp. 41-49. 
13. Erjavec, E., Rednak, M., Volk, T. (1998): The European Union enlargement - The case of agriculture in Slovenia. Food Policy, vol. 23, no. 5, pp. 395-409.

14. Estol, J., Font, X. (2016): European tourism policy: its evolution and structure. Tourism Management, vol. 52, pp. 230-241.

15. Everett, S., Aitchison, C. (2008): The role of gastronomy tourism in sustaining regional identity: a case study of Cornwall, South West England. Journal of Sustainable Tourism, vol. 16, no. 2, pp. 150-167.

16. Grum, B., Kobal Grum, D. (2014): Satisfaction with current residence status in comparison with expectations of real estate buyers in Slovenia and Serbia. Procedia Social And Behavioral Sciences, vol. 109, no. 8, pp. 263-275.

17. Gaddefors J. (2005): Creating context entrepreneurial opportunities in a consumer market setting. Journal of Enterprising Culture, vol. 13, no. 3, pp. 199-224.

18. Getz D., Carlsen J. (2005): Family business in tourism: State of the art. Annals of Tourism Research, vol. 32, no. 1, pp. $237-258$.

19. Getz D., Carlsen J. (2000): Characteristics and goals of family and owner-operated businesses in the rural tourism and hospitality sectors. Tourism Management, vol. 21, no. 6, pp. 547-560.

20. Gomezelj, O. D., Mihalič, T. (2008): Destination competitiveness - Applying different models, the case of Slovenia. Tourism Management, vol. 29, no. 2, pp. 294-307.

21. Hall, R.D. (1998): Tourism development and sustainability issues in Central and SouthEastern Europe. Tourism Management, vol. 19, no. 5, pp. 423-431.

22. Knežević, A.A., Cvelbar, Lj. (2011): Privatization, market competition, international attractiveness, management tenure and hotel performance: evidence from Slovenia. International Journal Of Hospitality Management, vol. 30, no. 2, pp. 391-397.

23. Košćak, M. (1998): Integral Development Of Rural Areas, Tourism And Village Renovation, Trebnje, Slovenia. Tourism Management, vol. 19, no. 1, pp. 81-85.

24. Komppula, R. (2014): The role of individual entrepreneurs in the development of competitiveness for a rural tourism destination - A case study. Tourism Management, vol. 40, pp. 361-371.

25. Lane B. (1994): What is rural tourism? Journal of Sustainable Tourism, vol. 2, no. 1-2, pp. 7-21

26. Lock, K., Gabrijelcic-Blenkus, M., Martuzzi, M., Otorepec, P., Kuhar, A., Robertson, A., Wallace, E., Dora, C., Maucec Zakotnic, J. (2004): Conducting an hia of the effect of accession to the European Union on national agriculture and food policy in Slovenia. Environmental Impact Assessment Review, vol. 24, no. 2, pp. 177-188.

27. Mulec, I., Wise, N. (2013): Indicating the competitiveness of Serbia's Vojvodina region as an emerging tourism destination. Tourism Management Perspectives, vol. 8, pp. 68-79.

28. Nastran, M. (2015): Why does nobody ask us? Impacts on local perception of a protected area in designation, Slovenia. Land Use Policy, vol. 46, pp. 38-49. 
29. Petrović-Ranđelović, M., Miletić, D. (2012): (No)competitiveness and sustainable development of Serbian tourism. Procedia - Social And Behavioral Sciences, vol. 44, pp. 78-87.

30. Petrović, M. D. (2014): Kvalitet agroturizma Vojvodine i njegov uticaj na stavove lokalnog stanovništva (Ph.D. thesis - in Serbian). University of Novi Sad, Faculty of Sciences, Department of Geography, Tourism and Hotel Management, Novi Sad, Serbia.

31. Petrović, M. D., Vujko, A., Blešić, I. (2015): Leisure Time in Countryside: The Health Aspects of Agritourism Activities. KNOWLEDGE - International Journal Scientific and Applicative papers, vol. 8, no. 1, pp. 131-136.

32. Petrović, M. D., Bjeljac, Ž., Demirović, D. (2016a): Tourism Impact Attitude Scale (TIAS) as a Tool of Contemporary Analysis in Agritourism. Agricultural Bulletin of Stavropol Region, no. 1, Supplement, pp. 13-19.

33. Petrović, M. D., Blešić, I., Ivolga, A., Vujko, A. (2016b): Agritourism Impact Toward Locals' Attitudes - An Evidence from Vojvodina Province (Serbia). Journal of the Geographical Institute "Jovan Cvijić” SASA, vol. 66, no. 1, pp. 105-123.

34. Rey, V., Groza, O. (2009): Balkans. International Encyclopedia Of Human Geography, pp. 265-272.

35. Sidali, K. L., Spiller, A., Schulze, B. (2011). Food, Agri-Culture and Tourism: Linking Local Gastronomy and Rural Tourism: Interdisciplinary Perspectives, Berlin: SpringerVerlag.

36. Srdanović, M., Pavić, D. (2015): Tourists' attitudes on tourism offer in north-western part of Montenegro. Journal of the Geographical Institute "Jovan Cvijić" SASA, vol. 65 , no. 2, pp. 201-214.

37. Šsprah, L., Novak, T., Fridl, J. (2014): The wellbeing of Slovenias population by region: comparison of indicators with an emphasis on health. Acta geographica Slovenica, vol. 54, no. 1, pp. 67-87.

38. Šmid-Hribar, M., Ledinek-Lozej, Š. (2013): The role of identifying and managing cultural values in rural development. Acta geographica Slovenica, vol. 53, no. 2, pp. 371-378.

39. Ursache, M. (2015): Tourism - significant driver shaping a destinations heritage. Procedia - social and Behavioral Sciences, vol. 188, no. 14, pp. 130-137.

40. Vujko, A., Gajić, T. (2014): The gouverment policy impact on economic development of tourism, Ekonomika poljoprivrede, vol. 61, no. 3, pp. 789-804. 


\title{
SLIČNOSTI I RAZLIKE RURALNOG TURIZMA SLOVENIJE I SRBIJE - PERCEPCIJA ZAPOSLENIH U TURISTIČKOM SEKTORU
}

\author{
Aleksandra Vujko ${ }^{6}$,Marko D. Petrovič ${ }^{7}$, Miloš Dragosavac $^{8}$, Tamara Gajič ${ }^{9}$
}

\section{Rezime}

Rad se bavi razvojem ruralnih područja u Sloveniji i Srbiji i prikazuje neke razlike/sličnosti između ove dve zemlje na osnovu percepcije 492 turističkih radnika. U radu se analiziraju glavni doprinosi ruralnog turizma i donosi niz predloga za buduća istraživanja. Glavni cilj rada je ukazati na pozitivne aspekte razvoja ruralnog turizma, kao i sličnosti i razlike Slovenije i Srbije. Podaci za ovu studiju su prikupljeni pomoću Dvajer i Kimovog (2003) Integrisanog modela konkurentnosti destinacije kojim se posmatraju ključne razlike/sličnosti ruralnog turizma Slovenije i Srbije. Determinante su obrađene pomoću ankete na bazi 24 indikatora zasnovanih na Likertovoj skali.

Ključne reči: ruralni turizam, Integrisani model konkurentnosti destinacije, Slovenija, Srbija

6 Dr Aleksandra Vujko, predavač, Visoka poslovna škola strukovnih studija, Ulica Vladimira Parića Valtera br. 4, Novi Sad, Srbija, Telefon: +381 6491426 45, E-mail: aleksandravujko@yahoo.com

7 Dr Marko D. Petrović, naučni saradnik, Geografski institut "Jovan Cvijić", SANU, Ulica Đure Jakšića br. 9, 11000 Beograd, Srbija, Email: m.petrovic@gi.sanu.ac.rs

8 Miloš Dragosavac, asistent, Visoka poslovna škola strukovnih studija, Ulica Vladimira Parića Valtera br. 4, Novi Sad, Srbija, E-mail: dragosavac.vps@gmail.com

9 Professor strukovnih studija, dr Tamara Gajić, Visoka poslovna škola strukovnih studija, Ulica Vladimira Parića Valtera br. 4, Novi Sad, Srbija, E-mail: gajic tamara@yahoo.com 